Technical Note

\title{
A Prototype Network for Remote Sensing Validation in China
}

\author{
Mingguo Ma ${ }^{1,2, *}$, Tao Che ${ }^{2,3}$, Xin $\mathrm{Li}^{2,3}$, Qing Xiao ${ }^{4}$, Kai Zhao ${ }^{5}$ and Xiaoping Xin ${ }^{6}$
}

1 School of Geographical Sciences, Southwest University, Beibei, Chongqing 400715, China

2 Heihe Remote Sensing Experimental Research Station, Cold and Arid Regions Environmental and Engineering Research Institute, Chinese Academy of Sciences, Lanzhou 730000, China; E-Mails: chetao@lzb.ac.cn (T.C.); lixin@1zb.ac.cn (X.L.)

3 Center for Excellence in Tibetan Plateau Earth Sciences, Chinese Academy of Sciences, Beijing 100101, China

4 Huailai Remote Sensing Test Station, Institute of Remote Sensing and Digital Earth, Chinese Academy of Sciences, Beijing 100094, China; E-Mail: xiaoqing@ radi.ac.cn

5 Changchun Jingyuetan Remote Sensing Experimental Station, Northeast Institute of Geography and Agroecology, Chinese Academy of Sciences, Changchun 130102, China;

E-Mail: zhaokai@iga.ac.cn

6 Hulunber Grassland Ecosystem Observation and Research Station, Institute of Agricultural Resources and Regional Planning, Chinese Academy of Agricultural Sciences, Beijing 100081, China; E-Mail: xinxiaoping@caas.cn

* Author to whom correspondence should be addressed; E-Mail: mmg@ swu.edu.cn; Tel./Fax: +86-23-6825-2370.

Academic Editors: Qinhuo Liu, Yuei-An Liou, Richard Müller and Prasad S. Thenkabail

Received: 16 December 2014 / Accepted: 20 April 2015 / Published: 24 April 2015

\begin{abstract}
Validation is an essential and important step before the application of remote sensing products. This paper introduces a prototype of the validation network for remote sensing products in China (VRPC). The VRPC aims to improve remote sensing products at a regional scale in China. These improvements will enhance the applicability of the key remote sensing products in understanding and interpretation of typical land surface processes in China. The framework of the VRPC is introduced first, including its four basic components. Then, the basic selection principles of the observation sites are described, and the principles for the validation of the remote sensing products are established. The VRPC will be realized in stages. In the first stage, four stations that have improved remote sensing observation facilities have been incorporated according to the selection principles. Certain core observation sites have been constructed at these stations. Next the Heihe Station is
\end{abstract}


introduced in detail as an example. The three levels of observation (the research base, pixel-scale validation sites, and regional coverage) adopted by the Heihe Station are carefully explained. The pixel-scale validation sites with nested multi-scale observation systems in this station are the most unique feature, and these sites aim to solve some key scientific problems associated with remote sensing product validation (e.g., the scale effect and scale transformation). Multi-year of in situ measurements will ensure the high accuracy and inter-annual validity of the land products, which will provide dynamic regional monitoring and simulation capabilities in China. The observation sites of the VRPC are open, with the goal of increasing cooperation and exchange with global programs.

Keywords: regional validation; validation network; remote sensing; remote sensing products; China

\section{Introduction}

An increasing number of earth observation satellites have been launched recently, and remote sensing technologies have continued to be developed [1]. The new sensors allow a large number of studies to produce abundant remote sensing products. New remote sensing retrieval algorithms have been emphasized by recent studies. Many projects have been launched to produce remote sensing products with long time series and global or regional coverage [2]. MODIS products are an example which comprise most varied class of products $[3,4]$. Validation of remote sensing products is important before the application of these products [5]. The Working Group on Calibration and Validation (WGCV) was established in 1984. Validation was defined by the WGCV as the process of assessing, by independent means, the quality of data products derived from system outputs [6]. The validation activities are defined as a means by which independent field, airborne, and other satellite data will be collected and used to assess the quality of remote sensing products [7].

Some validation plans have been implemented globally and regionally. For example, BigFoot as one of the earlier validation projects was initiated in 1999 [8,9]. Validation of the Land European Remote Sensing Instruments (VALERI) was initiated by the European Space Agency (ESA) at the beginning of the 21st century [6]. The Land Product Validation (LPV) was established by the Committee of the Earth Observation Satellites (CEOS) for proposing a consistent strategy and dedicated methods and tools for validation and intercomparison of land biophysical products [7]. The above validation studies mainly use in situ point observations to evaluate the estimation accuracy of remote sensing products. However, the representativeness of the in situ point observations with regard to the pixel scales of the remote sensing data is questionable, especially for datasets with coarse spatial resolution. The scale and the scale effect are key scientific problems and are critical for up-scaling the field observation data to moderate resolution [10]. Even with significant efforts towards solving these key scientific problems, the insufficient understanding of the validation of remote sensing products and the lack of validation theories and practical methods has delayed validation projects relative to the development of algorithms for remote sensing data retrieval, which limits further applications of remote sensing data and products [11]. 
Some newly developed and advanced observation methods, such as wireless sensor networks (WSN) [12, 13] and footprint observation [14-16], have been initiated recently and have the potential to contribute to the resolution of the scale effect challenge. For example, tens to hundreds of nodes with automatic, intelligent, and remote-controllable sensors were installed in a $5 \times 5 \mathrm{~km}$ region according to the spatial heterogeneity of the land surface parameters. These high-level, high-density, and automatic observation data can be used to measure the spatial distribution characteristics of eco-hydrological parameters (e.g., soil moisture, temperature, and LAI) and to develop scale transformation and validation methods [12]. Observations by eddy covariance (EC), large-aperture scintillometer (LAS), and cosmic-ray soil moisture/snow observing system (COSMOS) cover certain areas, with footprints of hundreds to thousands of meters [14-16].

Experiments were performed for data validation in the above projects. However, these experiments were regional and temporary. Some fixed sites can be used from existing networks such as the Aerosol Robotic NETwork (AERONET) [17], the Fluxnet Network (FLUXNET) [18], the Bench-mark Land Multisite Analysis and Intercomparison of Products (BELMANIP) [19], and the International Soil Moisture Network (ISMN) [20]. The underlying surface types of these sites normally include most typical land cover types. The data from these sites are continuous and comparable because they have uniform observation standards and data formats. However, these sites are not designed specifically for the validation of remote sensing products; therefore, it is difficult to meet the requirements of the node installation strategy for scale transformation and scale effect analysis.

Here we describe the design of a validation network for remote sensing products in China (VRPC). First, the fundamental idea and framework for this network are discussed. Then, we introduce the design of the core observation sites in China and the four stations involved in this network in the first stage of the VRPC. Finally, the Heihe Remote Sensing Experimental Research Station is described as an example of how to solve problems encountered in existing validation approaches, such as scale, scale effect, and scale transformation.

\section{Framework of the VRPC}

Figure 1 shows the framework of the VPRC, which includes four basic components. The first element is the design and construction of the observation stations and sites. The stations will be selected according to several principles. The existing bases and resources for remote sensing product validation need to be considered first. The sites involved in the stations need to be adequately typical and representative, while also being relatively heterogeneous over a sufficient area. The installation of observation systems must fully consider the spatial distribution characteristics of the underlying surface. Thus, prior knowledge of the key parameters of the sites' land surface need to be acquired and the installation strategy needs to be optimized based on prior knowledge [12].

The validation stations can be divided into two main types. The first type consists of one core site or several core sites, which are set up especially for validation of remote sensing products. These sites normally have special observation techniques such as unmanned aerial vehicles, ground-based remote-sensing platforms, and wireless sensor networks (WSN). Simultaneous satellite-airborne-ground experiments, ground-based remote sensing control experiments, and intensive ground experiments can be launched periodically. The theories and methodologies for the scale transformation and validation are 
studied based on these thematic experiments. The second type of validation station is based on other existing observation networks, such as the Chinese Ecosystem Research Network (CERN), the Chinese Terrestrial Ecosystem Flux Research Network (ChinaFLUX), and the High-Cold Region Observation and Research Network for Land Surface Processes and Environment (HORN). The stations for these networks are set up for special scientific aims. Based on their existing observation base and systems, some improvements can be processed for the demands of remote sensing validation. Then, these sites can perform some continuous and fixed observations. The obtained data are normally used to validate remote sensing products directly based on theories and methodologies.

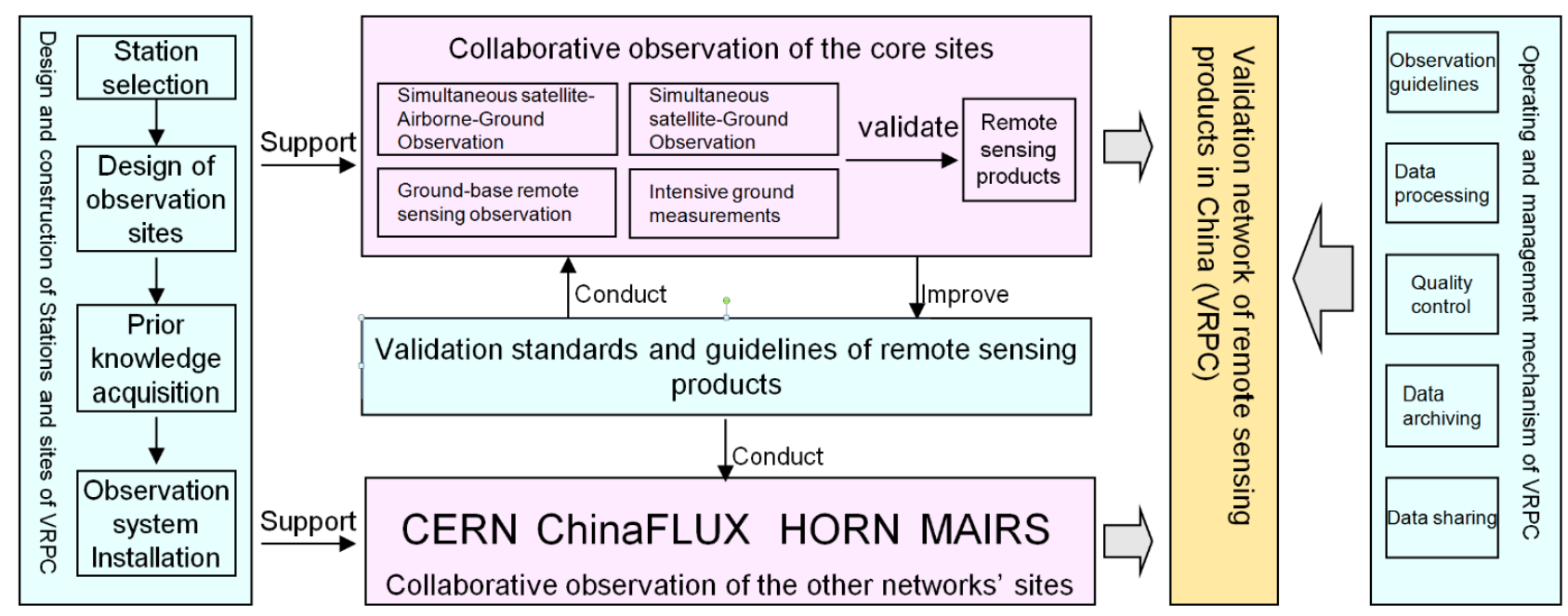

Figure 1. Framework of the VRPC.

Some validation standards and guidelines for remote sensing products are being studied and formulated for a special project. These standards and guidelines can be used to construct the sites and to establish collaborations with other networks' sites. The results of the applications and the theory or methodology studies can be used to improve the standards and guidelines.

Some operation and management mechanisms also need to be formulated for the VRPC. These mechanisms include in situ observation guidelines, data processing guidelines, data quality control guidelines, data archiving guidelines, and data sharing regulations, and they need to be discussed by administrative and technological staff of the core sites.

The above four basic components constitute the VPRC. The selection of the stations and core sites is the basis of the observations, and the pixel-scale observation sites need to be constructed, which represents the largest difference between normal stations and the VPRC's stations. The validation standards and guidelines are the theoretical basis. Scale is the key problem in the validation strategies for different remote sensing retrieval variables, and a great deal of research is required on this topic. The management mechanisms are the operating basis for the collaborative observation network in China, which ensures that the data are consistent and shared. The core sites of the special remote sensing stations and other stations involved in existing observation networks are the platform for the in situ measurements of several atmospheric and land surface parameters. The prototype design above needs to be practiced on these platforms. Additionally, the design can be improved according to the application practices. The settings of the core sites are involved in the validation strategies. Thus, the settings affect the validation strategies. 
The basic selection principles of the observation sites are defined for the VPRC. The first principle is representativeness. The observation sites can cover the largest percentage of land cover types, which include typical ecosystem types and vegetation processes affected by different climatic conditions and landforms in China. The second principle is openness. This concept stipulates that the observation sites should be as the experiment and research platforms for most researchers and students (including foreigners). Therefore, these sites cannot be close to the non-open areas or military bases. The third principle is practicality. The observation sites should be located in regions with convenient transportation, comprehensive logistics support, and good communications. Proximity to a civil airport is preferred. The fourth principle is combination. The observation sites can support multiple elements of remote sensing calibration and validation. For example, the observation site includes several experimental areas with uniform underlying surfaces.

\section{Core Sites and Preliminary Stations of the VRPC}

After a comprehensive study of local geographical and climatic features, ecosystem representatives, infrastructure and observation facilities, we plan to reform and construct approximately 12 observation fields distributed in seven areas in China as the core observation fields of the national remote sensing products validation network (Figure 2). During the first period of the project execution (2012-2014), we bring four remote sensing stations with the best infrastructure and observation facilities into the remote sensing national validation network as a pilot for collaborative networking experiments for satellite-airborne-ground synchronous observations and the validation of remote sensing products. For each station, several standard observation fields with dimensions of $3 \mathrm{~km} \times 3 \mathrm{~km}$ will be established for remote sensing product validation. Because China is a mountainous country and the mountainous and hilly areas make up about $43 \%$ of the total area, the observation fields will have at least an area of $2 \mathrm{~km} \times 2 \mathrm{~km}$ in these regions with fragmented landscapes. Observation fields that are used for validating the soil moisture inverted by passive microwaves will have areas of $25 \mathrm{~km} \times 25 \mathrm{~km}$.

For every standard observation field that is planned to be built, we have used the regional multi-resolution satellite images (e.g., Quickbird and TM) and ground survey (e.g., leaf area index, soil moisture, land surface temperature, land cover) to calculate the background values of the observed elements for the target area. The other background values will also be collected, such as digital elevation model data and soil property data. Furthermore, based on the above prior knowledge of the observation fields, we used the layout optimization approaches of the heterogeneous pixel scale from the first part of the project to design all elements of the ground observation systems in the experiment fields [21,22]. Subsequently, we deployed observation nodes and facilities. The observation systems will contain a multi-scale nested layout mode (i.e., the sensor network (with a 1 10 km scale)), a large-aperture scintillometer (with a $1 \mathrm{~km}$ scale), eddy covariance (with a $100 \mathrm{~m}$ scale), ground-based remote sensing (with a $1 \mathrm{~m}$ scale), and in situ point observations) to manage the validation of remote sensing products with various resolutions.

According to the selection principles of the observation sites and the preliminary design of the core sites, four existing stations were selected for inclusion in the first stage of the VRPC. They are the Heihe Remote Sensing Experimental Research Station (Heihe Station), the Huailai Remote Sensing Test Station (Huailai Station), the Changchun Jingyuetan Remote Sensing Experimental Station (Jingyuetan 
Station), and the Hulunber Grassland Ecosystem Observation and Research Station (Hulunber Station). The locations of these four stations are shown in Figure 2. Table 1 provides the summary information for each observation site of the three stations, including longitude, latitude, elevation, total annual precipitation, average annual temperature, land cover, LAI, and core scientific aims. The summary information for Heihe Station is shown in Table 2.

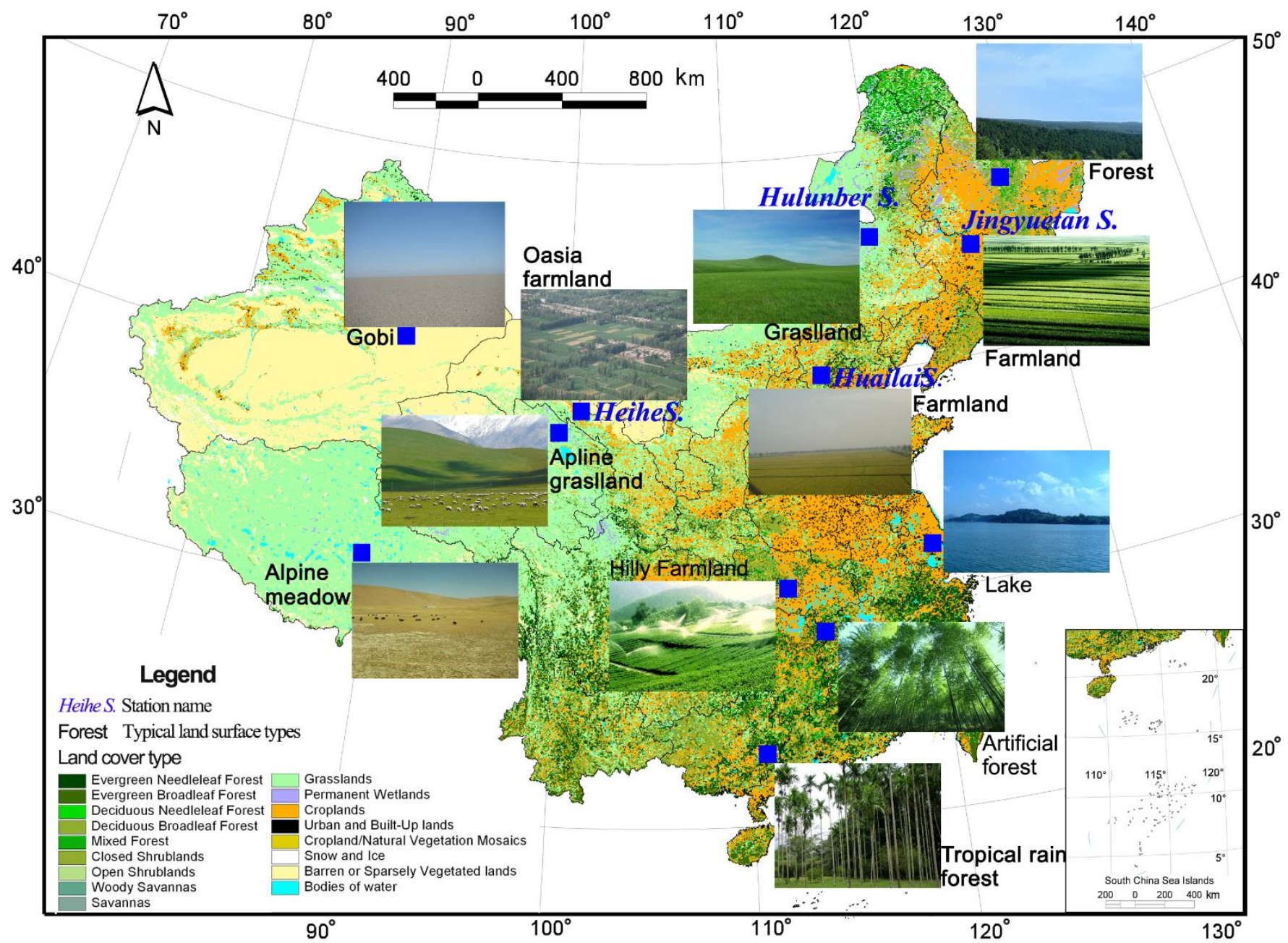

Figure 2. Core sites of the VRPC and their land cover types.

Table 1. Information on the core observation sites for the validation network for remote sensing products in China (VRPC).

\begin{tabular}{|c|c|c|c|c|c|}
\hline $\begin{array}{l}\text { Station } \\
\text { Name }\end{array}$ & $\begin{array}{l}\text { Core Site } \\
\text { (Science Network) }\end{array}$ & Location & Meteorology & Land Cover & Scientific Aims \\
\hline $\begin{array}{l}\text { Huailai } \\
\text { Station }\end{array}$ & $\begin{array}{l}\text { East garden controlled } \\
\text { experimental site (RSON) } \\
100 \mathrm{~m} \times 100 \mathrm{~m}\end{array}$ & $\begin{array}{l}\text { Prov.: Hebei; } \\
\text { Long.:115.783; } \\
\text { Lat.: 40.349; Ele.: } 488\end{array}$ & $\begin{array}{l}\text { Precip.: } 650 \\
\text { Temp.: } 10\end{array}$ & $\begin{array}{l}\text { Type: Cropland; } \\
\text { LAI: } 6.5\end{array}$ & $\begin{array}{l}\text { Remote sensing } \\
\text { mechanism; scale }\end{array}$ \\
\hline $\begin{array}{l}\text { Huailai } \\
\text { Station }\end{array}$ & $\begin{array}{l}\text { East garden (RSON) } \\
1.5 \mathrm{~km} \times 2 \mathrm{~km}\end{array}$ & $\begin{array}{l}\text { Prov.: Hebei; } \\
\text { Long.: 115.783; } \\
\text { Lat.: 40.349; Ele.: } 488\end{array}$ & $\begin{array}{l}\text { Precip.: } 650 \\
\text { Temp.: } 10\end{array}$ & $\begin{array}{l}\text { Type: Cropland; } \\
\text { LAI: } 6.5\end{array}$ & $\begin{array}{l}\text { Remote sensing } \\
\text { mechanism; ecological } \\
\text { protection; crop growth } \\
\text { simulation model }\end{array}$ \\
\hline
\end{tabular}


Table 1. Cont.

\begin{tabular}{|c|c|c|c|c|c|}
\hline $\begin{array}{l}\text { Station } \\
\text { Name }\end{array}$ & $\begin{array}{l}\text { Core Site } \\
\text { (Science Network) }\end{array}$ & Location & Meteorology & Land Cover & Scientific Aims \\
\hline $\begin{array}{l}\text { Huailai } \\
\text { Station }\end{array}$ & $\begin{array}{l}\text { Guanting reservoir } \\
(\mathrm{RSON}) \\
2 \mathrm{~km} \times 2 \mathrm{~km}\end{array}$ & $\begin{array}{l}\text { Prov.: Hebei; } \\
\text { Long.: } 115.740 ; \\
\text { Lat.: 40.352; Ele.: } 475\end{array}$ & $\begin{array}{l}\text { Precip.: } 650 \text {; } \\
\text { Temp.: } 9\end{array}$ & $\begin{array}{l}\text { Type: Water; } \\
\text { LAI: } 0\end{array}$ & $\begin{array}{l}\text { Ecological protection; } \\
\text { water resource } \\
\text { utilization }\end{array}$ \\
\hline $\begin{array}{l}\text { Jingyuetan } \\
\text { Station }\end{array}$ & $\begin{array}{l}\text { Taipingpu controlled } \\
\text { experimental site (RSON) } \\
200 \mathrm{~m} \times 200 \mathrm{~m}\end{array}$ & $\begin{array}{l}\text { Prov.: Jilin; } \\
\text { Long.: } 125.401 \text {; } \\
\text { Lat.: 43.998; Ele.: } 211\end{array}$ & $\begin{array}{l}\text { Precip.: 520; } \\
\text { Temp.: } 4.4\end{array}$ & $\begin{array}{l}\text { Type: Cropland; } \\
\text { LAI: } 4\end{array}$ & $\begin{array}{l}\text { Radiative transfer } \\
\text { theory; soil freezing } \\
\text { process; scale }\end{array}$ \\
\hline $\begin{array}{l}\text { Jingyuetan } \\
\text { Station }\end{array}$ & $\begin{array}{l}\text { Dehui corn(RSON) } \\
2 \mathrm{~km} \times 2 \mathrm{~km}\end{array}$ & $\begin{array}{l}\text { Prov.: Jilin; Long.: } \\
\text { 125.360; Lat.: } 44.119 \text {; } \\
\text { Ele.: } 207\end{array}$ & $\begin{array}{l}\text { Precip.: 604; } \\
\text { Temp.: } 4.8\end{array}$ & $\begin{array}{l}\text { Type: Cropland; } \\
\text { LAI: } 5\end{array}$ & $\begin{array}{l}\text { Validation; water } \\
\text { balance; crop simulation } \\
\text { growth model }\end{array}$ \\
\hline $\begin{array}{l}\text { Hulunber } \\
\text { Station }\end{array}$ & $\begin{array}{l}\text { Stipa baicalensis site } \\
(\mathrm{CERN}) \\
3 \mathrm{~km} \times 3 \mathrm{~km}\end{array}$ & $\begin{array}{l}\text { Prov.: Inner Mongolia; } \\
\text { Long.: } 120.087 \text {; } \\
\text { Lat.: 49.342; Ele.: } 642\end{array}$ & $\begin{array}{l}\text { Precip.: } 380 \\
\text { Temp.: }-1.0\end{array}$ & $\begin{array}{l}\text { Type: Temperate } \\
\text { meadow steppe; } \\
\text { LAI: } 2.5\end{array}$ & $\begin{array}{l}\text { Validation; grassland } \\
\text { ecosystem process model }\end{array}$ \\
\hline $\begin{array}{l}\text { Hulunber } \\
\text { Station }\end{array}$ & $\begin{array}{l}\text { Cropland site (CERN) } \\
3 \mathrm{~km} \times 3 \mathrm{~km}\end{array}$ & $\begin{array}{l}\text { Prov.: Inner Mongolia; } \\
\text { Long.: } 120.034 \text {; } \\
\text { Lat.: } 49.308 \text {; Ele.: } 638\end{array}$ & $\begin{array}{l}\text { Precip.: } 380 \\
\text { Temp.: }-1.0\end{array}$ & $\begin{array}{l}\text { Type: Cropland; } \\
\text { LAI: } 4\end{array}$ & $\begin{array}{l}\text { Validation; crop } \\
\text { simulation growth model }\end{array}$ \\
\hline
\end{tabular}

Precip.: Precipitation (mm); Temp.: Temperature $\left({ }^{\circ} \mathrm{C}\right)$; Prov.: Province; Long.: Longitude $\left({ }^{\circ}\right.$ E); Lat.: Latitude $\left({ }^{\circ} \mathrm{N}\right)$; Ele.: Elevation $(\mathrm{m})$.

\section{Example from the Heihe Station}

The Heihe River Basin (HRB) is a typical inland river basin in the northwestern arid and semi-arid regions of China. Two simultaneous airborne, satellite-borne, and ground-based remote sensing experiments have been designed and performed in the HRB since 2007. The Watershed Allied Telemetry Experimental Research (WATER) project was conducted during 2007 and 2008 [22]. The remote sensing experimental areas and observation system were constructed preliminarily in the HRB, which is the foundation for the establishment of the Heihe Station. A new experiment, the Heihe Watershed Allied Telemetry Experimental Research (HiWATER), has been ongoing in the HRB since 2012 and is expected to continue into 2015 [23]. The Heihe Station was founded in 2009 by the Cold and Arid Regions Environmental and Engineering Research Institute (CAREERI), Chinese Academy of Sciences (CAS), based on the WATER and HiWATER projects.

Heihe Station has adopted three levels of observation: A research base, pixel-scale validation sites, and regional coverage. The research base of the station is located in the Ganzhou District, Zhangye City $\left(100.48^{\circ} \mathrm{E}, 38.83^{\circ} \mathrm{N}\right)$ in the middle reaches of the $\mathrm{HRB}$ and is surrounded by artificial oasis, low-mountain desert, Gobi desert, and wetland landscapes. The research baseis convenient for it is situated next to the Zhangye Airport, the Lanzhou-Xinjiang High-speed Railway, and the Lianyungang-Horgas Highway. The controlled experimental site has been constructed at the base, and ground-based remote sensing experiments with multiple bands, angles, and polarizations can be conducted for remote sensing mechanism studies in the cold and arid regions of China. 
Table 2. Roles and characteristics of the core remote sensing validation sites in the Heihe River Basin (HRB).

\begin{tabular}{|c|c|c|c|c|}
\hline Experimental Area & Validation Site & Aims, Validation Variables, and Scales & Observation Methods & Basic Information \\
\hline $\begin{array}{l}\text { Heihe Station Base } \\
\left(100.48^{\circ} \mathrm{E}, 38.83^{\circ} \mathrm{N}\right. \\
\left.20,000 \mathrm{~m}^{2}\right)\end{array}$ & $\begin{array}{l}\text { Dawuhao controlled } \\
\text { experimental site } \\
(100 \mathrm{~m} \times 150 \mathrm{~m})\end{array}$ & $\begin{array}{l}\text { Aims: Remote sensing mechanism, scale; Observation } \\
\text { variables: Reflectance, emissivity, and brightness } \\
\text { temperature measurements with multiple angles and } \\
\text { polarizations; Scale: } 1 \mathrm{~m}-30 \mathrm{~m}\end{array}$ & $\begin{array}{l}\text { AWS, Track crane } \\
\text { ground-based remote } \\
\text { sensing platform, WSN }\end{array}$ & $\begin{array}{l}\text { Precip.: } 110 \mathrm{~mm} \text {; temp.: } 7.8^{\circ} \mathrm{C} \text {; LUCC: Cropland; } \\
\text { LAI: 5; science network: RSON; Prov.: Gansu; } \\
\text { Long.: 100.372; Lat.: } 38.856 \text {; Ele: } 1524 \text {. }\end{array}$ \\
\hline \multirow{3}{*}{$\begin{array}{l}\text { Babao River Basin } \\
\left(100.1-101.15^{\circ} \mathrm{E}\right. \\
37.72-38.32^{\circ} \mathrm{N} \\
\left.2452 \mathrm{~km}^{2}\right)\end{array}$} & $\begin{array}{l}\text { Babao River Basin } \\
\left(2452 \mathrm{~km}^{2}\right)\end{array}$ & $\begin{array}{l}\text { Aims: Hydrological model driving, validation; } \\
\text { Validation variables: Snow depth, rainfall, LST, soil moisture, } \\
\text { soil freeze/thaw, radiation, FPAR, and albedo; } \\
\text { Scale: } 1 \mathrm{~km}-25 \mathrm{~km}\end{array}$ & $\begin{array}{l}\text { AWS (5), SMTMS (5), AR } \\
\text { Superstation, and } \\
\text { WATERNET1 }\end{array}$ & $\begin{array}{l}\text { Precip.: 270-670 mm; temp.: } 1.0^{\circ} \mathrm{C} \text {; LUCC: Alpine } \\
\text { meadow, cold desert, forest, shrub; science network: } \\
\text { IMSN, RSON. Prov.: Qinghai; Long.: 100.1-101.15; } \\
\text { Lat.: 37.72-38.32; Ele.: 2640-5000 }\end{array}$ \\
\hline & $\begin{array}{l}\text { A'rou freeze/thaw } \\
\text { observation site } \\
(2 \mathrm{~km} \times 2 \mathrm{~km})\end{array}$ & $\begin{array}{l}\text { Aims: DHM and LSM development, validation, scale; } \\
\text { Validation variables: ET, carbon flux, soil moisture, soil } \\
\text { freeze/thaw, radiation, LST, LAI, FPAR, and albedo; } \\
\text { Scale: } 30 \mathrm{~m}-1 \mathrm{~km}\end{array}$ & $\begin{array}{l}\text { AR Superstation, EC, LAS, } \\
\text { COMOS, and SoilNET }\end{array}$ & $\begin{array}{l}\text { Precip.: } 450 \mathrm{~mm} \text {; temp.: }-0.6^{\circ} \mathrm{C} \text {; LUCC: Alpine } \\
\text { meadow; LAI: 3.5; science network: ChinaFLUX, } \\
\text { IMSN, RSON. Prov.: Qinghai; Long.: 100.465; Lat.: } \\
\text { 38.044; Ele.: } 3033\end{array}$ \\
\hline & $\begin{array}{l}\text { Binggou snow } \\
\text { observation site } \\
(2 \mathrm{~km} \times 2 \mathrm{~km})\end{array}$ & $\begin{array}{l}\text { Aims: SRM and DHM development, validation, scale; } \\
\text { Validation variables: ET, carbon flux, snow cover, snow } \\
\text { water equivalent, and snow grain size; } \\
\text { Scale: } 30 \mathrm{~m}-1 \mathrm{~km}\end{array}$ & $\begin{array}{l}\text { AWS, SMTMS, EC, snow } \\
\text { pillow, SWS, GMON SWE, } \\
\text { snow stakes, and blowing } \\
\text { snow }\end{array}$ & $\begin{array}{l}\text { Precip.: } 600 \mathrm{~mm} \text {; temp.: }-4.5^{\circ} \mathrm{C} \text {; LUCC: Cold } \\
\text { desert; science network: RSON. Prov.: Qinghai; } \\
\text { Long.: } 100.239 \text {; Lat.: } 38.014 \text {; Ele.: } 4131\end{array}$ \\
\hline \multirow{3}{*}{$\begin{array}{l}\text { Zhangye Artificial } \\
\text { Oasis } \\
\left(100.22-100.55^{\circ} \mathrm{E}\right. \\
38.71-38.99^{\circ} \mathrm{N} \\
\left.900 \mathrm{~km}^{2}\right)\end{array}$} & $\begin{array}{l}\text { Daman farmland } \\
\text { observation site } \\
(3 \mathrm{~km} \times 3 \mathrm{~km})\end{array}$ & $\begin{array}{l}\text { Aims: Irrigation optimization, IHEM development, } \\
\text { validation, scale; } \\
\text { Validation variables: ET, carbon flux, LAI, radiation, LAI, VF, } \\
\text { LST, soil moisture, FPAR, albedo, aerosol, and } \mathrm{CO}_{2} \text {; } \\
\text { Scale: } 30 \mathrm{~m}-1 \mathrm{~km}\end{array}$ & $\begin{array}{l}\text { DM Superstation, EC, LAS, } \\
\text { COMOS, CE318, lysimeter, } \\
\text { LAINET (15), and } \\
\text { WATERNET2 }\end{array}$ & $\begin{array}{l}\text { Precip.: } 100 \mathrm{~mm} \text {; Temp.: } 8.0^{\circ} \mathrm{C} \text {; LUCC: Cropland; } \\
\text { LAI: 5; science network: ChinaFLUX, IMSN, } \\
\text { RSON; Prov.: Gansu; Long.: 100.372; Lat.: } 38.856 \text {; } \\
\text { Ele.: } 1556 .\end{array}$ \\
\hline & $\begin{array}{l}\text { Huazhaizi desert } \\
\text { observation site } \\
(3 \mathrm{~km} \times 3 \mathrm{~km})\end{array}$ & $\begin{array}{l}\text { Aims: Ecological protection, sand prevention, water } \\
\text { balance, validation; } \\
\text { Validation variables: ET, carbon flux LAI, radiation, LAI, } \\
\text { LST, soil moisture, FPAR, and albedo; } \\
\text { Scale: } 30 \mathrm{~m}-1 \mathrm{~km}\end{array}$ & AWS, EC, and SMTMS & $\begin{array}{l}\text { Precip.: } 150 \text { mm; Temp.: } 9.0^{\circ} \mathrm{C} \text {; LUCC: Farmland; } \\
\text { science network: RSON; Prov.: Gansu; Long.: } \\
\text { 100.446; Lat.: } 38.975 \text {; Ele.: } 1460 .\end{array}$ \\
\hline & $\begin{array}{l}\text { Zhangye northern } \\
\text { suburb wetland } \\
\text { observation site } \\
(2 \mathrm{~km} \times 2 \mathrm{~km})\end{array}$ & $\begin{array}{l}\text { Aims: Ecological protection, water balance, integrated } \\
\text { model, validation; } \\
\text { Validation variables: ET, carbon flux LAI, radiation, LAI, } \\
\text { LST, soil moisture, FPAR, and albedo; } \\
\text { Scale: } 30 \mathrm{~m}-1 \mathrm{~km}\end{array}$ & AWS, EC, and SMTMS & $\begin{array}{l}\text { Precip.: } 100 \mathrm{~mm} \text {; Temp.: } 12.1^{\circ} \mathrm{C} \text {; LUCC: Wetland; } \\
\text { LAI: 4; science network: RSON; Prov.: Gansu; } \\
\text { Long.: } 100.446 \text {; Lat.: } 38.975 \text {; Ele.: } 1460 .\end{array}$ \\
\hline
\end{tabular}


Table 2.Cont.

\begin{tabular}{|c|c|c|c|c|}
\hline Experimental Area & Validation Site & Aims, Validation Variables, and Scales & Observation Methods & Basic Information \\
\hline $\begin{array}{l}\text { Ejin Banner } \\
\text { Natural Oasis } \\
\left(100.22-100.55^{\circ} \mathrm{E},\right. \\
\left.38.71-38.99^{\circ} \mathrm{N}, 8 \mathrm{~km}^{2}\right)\end{array}$ & $\begin{array}{l}\text { Sidaoqiao natural } \\
\text { oasis site } \\
(4 \mathrm{~km} \times 2 \mathrm{~km})\end{array}$ & $\begin{array}{l}\text { Aims: Ecological protection, IHEM development, } \\
\text { validation, scale; } \\
\text { Validation variables: ET, carbon flux, LAI, radiation, } \\
\text { LAI, LST, FPAR, and albedo; } \\
\text { Scale: } 30 \mathrm{~m}-1 \mathrm{~km}\end{array}$ & $\begin{array}{l}\text { SDQ Superstation, EC, } \\
\text { LAS, and SoilNET }\end{array}$ & $\begin{array}{l}\text { Precip.: } 37 \mathrm{~mm} \text {; Temp.: } 8.3^{\circ} \mathrm{C} \text {; LUCC: Mixed forest and } \\
\text { shrubland; LAI: 1.5; science network: RSON; Prov.: } \\
\text { Inner Mongolia; Long.: } 101.133 \text {; Lat.: } 41.990 \text {; Ele.: } 876 \text {. }\end{array}$ \\
\hline
\end{tabular}

AWS: Automatic weather station, including wind speed, air temperature and humidity, wind direction, air pressure, rainfall, snow depth, PAR, LST, and four components of radiation; SMTMS: Soil moisture and temperature measurement system, including temperature and moisture profile (6, the number of the sensors, same as below), heat flux (3), and average soil temperature (2); AR Superstation: A'rou Superstation, including wind speed(6), air temperature(6), humidity(6), wind direction, air pressure, PAR, LST, four components of radiation, rainfall, snow depth, soil moisture (20), and soil temperature (20), soil heat conductivity (6), soil water potential (6), heat flux (3), and average soil temperature (2); DM Superstation: Daman Superstation, including wind speed (7), air temperature (7), humidity (7), $\mathrm{CO}_{2}$ concentration (7), wind direction, air pressure, PAR, LST (2), and four components of radiation, rainfall, soil moisture (7), soil temperature (8), heat flux (3), and average soil temperature (2); SDQ Superstation: Sidaoqiao Superstation, including wind speed (7), air temperature(7), humidity (7), wind direction, air pressure, PAR, LST (2), four components of radiation, rainfall, soil moisture (8), soil temperature (9), heat flux (3), average soil temperature (2), and stem sap flow(6); WATERNET1: WSN (40 nodes), including soil moisture (80), soil temperature (80), LST (19), snow depth (11), and rainfall(11); WATERNET2: WSN (10 nodes), including soil moisture (20), soil temperature (20), and LST (10); SoilNET: WSN (16 nodes), including soil moisture (64) and soil temperature (64); LSM: Land surface model; SRM: Snow runoff model; DHM: Distributed hydrological model; IHEM: Integrated hydrological and ecological model; SWS: Snow water sensor and Gamma Monitor snow water equivalent (GMON SWE); Precip.: Precipitation; Temp.: Temperature; Prov.: Province; Long.: Longitude $\left({ }^{\circ} \mathrm{E}\right)$; Lat.: Latitude $\left({ }^{\circ} \mathrm{N}\right)$; Ele.: Elevation (m). 
Several pixel-scale validation sites involved in three remote sensing experimental areas based on HiWATER will be continuously maintained by the Heihe Station. One is the Babao River Basin, which includes three validation sites. The second is the Zhangye artificial oasis, which also includes three validation sites. The last is the Ejin Banner natural oasis, which is dominated by Populuseuphratica, Tamarix, and other arid region species. Some detailed information and instrumentation placement maps can be found in the introduction by Li et al. [23]. Table 2 shows the roles and the characteristics of the core remote sensing validation sites in the HRB. Figure 3 shows the distribution of these validation sites in the HRB. These validation sites were initially designed and established following the BigFoot Project's scheme. However, we use additional nested multi-scale observation systems (Figure 4). For example, the Daman farmland observation site includes observations on the kilometer scale (LAS, COSMOS), hundred-meter scale (EC) and meter scale (Lysimeter, WSN, and AWS), which can be used to validate evapotranspiration (ET) products at different scales [16]. These observations can also be used to analyze the scale effect and to develop a scale transformation method [24]. The scale effect and scale transformation in remote sensing product validation are still a great challenge in the long term. Resolving these issues is the core scientific aim of the Heihe Station and the VRPC. Our observation activities and studies will focus on this topic continuously.

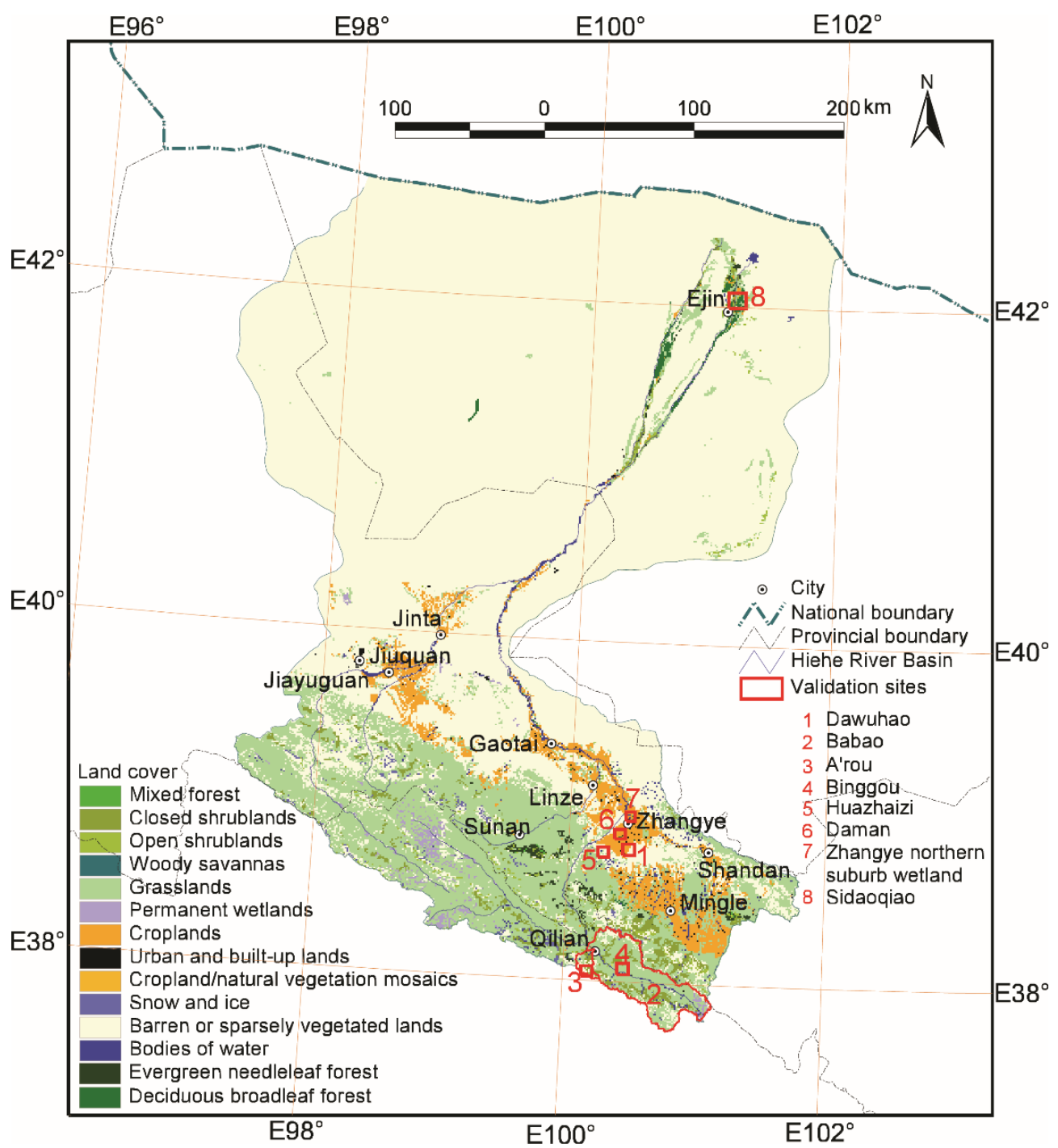

Figure 3. Distribution of the validation sites in the HRB. 


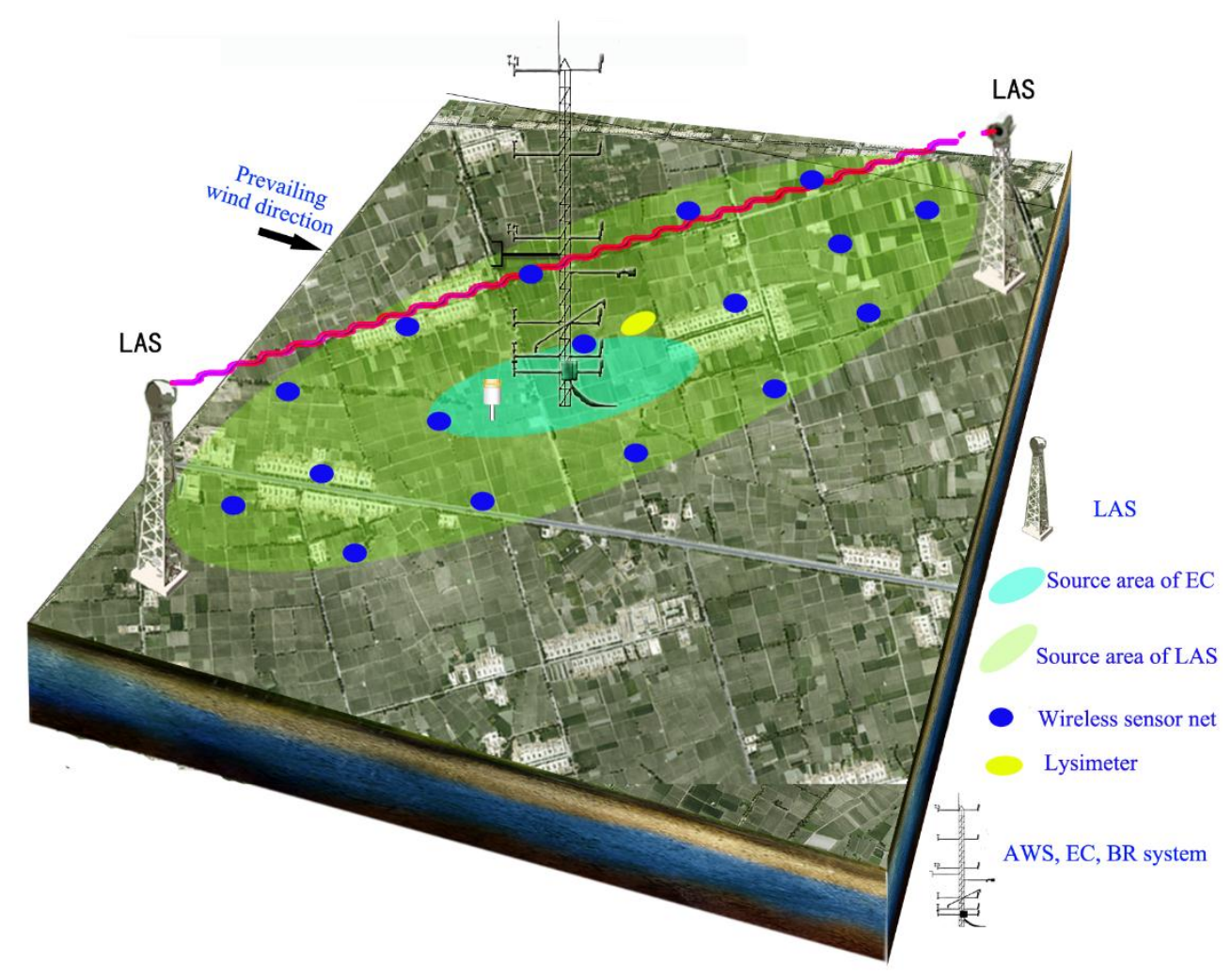

Figure 4. Nested multi-scale observation systems.

At the Heihe Station, WSN is adopted widely to realize continuous, high-frequency, multi-point data acquisition of key ecological and hydrological parameters, such as LAI, FPAR, vegetation coverage, land surface temperature (LST), albedo, soil moisture, soil temperature, and snow depth; these parameters can be used to capture the spatiotemporal variations of key eco-hydrological parameters over a heterogeneous land surface at a remote sensing pixel scale [12,24]. In practice, the sampling optimization method can consider the relationship of a target variable and environmental variables and can calculate the spatial autocorrelation of regression residuals to obtain the optimization design for the WSN nodes in the geographic space and simultaneously attribute that space at the Heihe Station [21,22,25].

To date, the Heihe Station has accumulated more than six years of ground-based observation data. Satellite data and airborne data during the same period are also obtained [23,24]. These data have been widely used to validate the remote sensing products and to develop the remote sensing retrieval algorithms in the HRB. The validated and estimated variables include LAI [26-28], Gross Primary Productivity (GPP) [29], ET [15], LST [30], snow depth [31], and soil moisture [32]. The data are available for using and sharing online through the website of the Cold and Arid Regions Scientific Data Center.

\section{Discussion}

\subsection{Promotion of Scientific Significances by VRPC}

To improve land surface models, hydrological models, ecological models at global and regional scales, numerous remote sensing products have been produced from different satellite data sources have been used in these models as the key inputs of driving, parameter, and process variables. Due to their 
broad coverage and continuous observation, remote sensing products have certain irreplaceable monitoring and simulating advantages in regional applications. Remote sensing data or products can also be used in a land data assimilation system as global and regional measurements. However, the quantity, quality, and spatial or temporal resolutions of global remote sensing products need to be improved significantly for regional applications. Improvement is necessary mainly because the parameter definition at the global scale is not sufficiently detailed for certain special regions (e.g., China). Many validation studies indicate that the quality of remote sensing products is relatively low and can be greatly improved. However, further improvement requires the definition of detailed parameters based on in situ observation results. The VRPC aims to improve remote sensing products at a regional scale of China in order to increase the applicability of these products in understanding and interpretation of typical land surface processes [33].

\subsection{Comparisons between the VRPC and Existing Networks}

Although several other validation plans mentioned in the introduction have been launched by research groups or experimental projects, the VRPC is still important for the regional development and validation of remote sensing products in China. Firstly, the observation fields of the VPRC are selected and designed especially for obtaining the "ground truth" values for the remote sensing pixels at different scales. However, the existing stations (e.g., CERN) are designed for the particular ecosystem and the observation elements focus on special scales, such as individuals, populations, community, ecosystems. Secondly, the nested multi-scale observation systems are designed and constructed especially for the validation of remote sensing data in VRPC. The existing stations in China don't normally have these kinds of integrated systems. Normally partial instruments are just used by these stations, such as EC and LAS. Thirdly, continuous in situ observation data are necessary to validate and improve remote sensing data. Current validation projects estimate the product accuracy for a single time or over a short time period. However, remote sensing products need to be validated at irregular intervals because of sensor drift and environmental changes. Therefore, proper maintenance, multi-year monitoring and steady funding should be ensured from different departments. Lastly, there are big differences in the observation elements between the VRPC and the other existing stations. Therefore, the construction of the VRPC will be an important complement to the validation networks around the world.

\subsection{Prospects of the VRPC in Future Years}

Although the VRPC was funded by the National High-Tech Program (863) of China and the budget was limited, the four stations selected in the first stage have formed a solid foundation. Heihe Station, Huailai Station, and Jingyuetan Station were included in the Remote Sensing Experimental Research and Ground-based Observation Network of Chinese Academy of Sciences (CAS-RSON), which was established in April 2014. The Hulunber Station belongs to the CERN. Therefore, these four stations have fixed and continued funding support, which ensures the systematic and continued acquisition of data for regional remote sensing product validation in China.

Additional efforts are still needed to promote future validation efforts. First, ground-based observation settings and validation strategies need to be discussed and optimized, and general and practical validation standards should be proposed by a global professional team for each remote sensing 
product. Second, the representation and deviation of ground-based observations need to be carefully analyzed, and the scale effect and the scale transformation method need to be resolved in order to properly prepare the validations of remote sensing products based on in situ multi-point or footprint observation data [34]. Third, even though this paper only provides a prototype of the VRPC and there are only four stations in the first stage, more stations are under consideration for the VRPC's stations and core sites. Funding support is anticipated from the Ministry of Science and Technology of the Republic of China (MOST) and CAS. The expanded number of stations will increase the representativeness of typical land covers in China, which will improve the validation level of Chinese remote sensing products. Finally, the optimal use of observational resources from other existing observation networks is critical to increase spatial sample numbers. However, gaps exist between the observation strategies of these networks and the data demands of remote sensing product validation. We aim to reduce these gaps by processing and analyzing the data effectively, which may include optimizing special instrument settings or improving existing observation resources.

\section{Conclusions}

A prototype network for remote sensing validation in China, VRPC, was designed for regional application in China. This is the first step to promote the validation of remote sensing products globally. Some conclusions from the VRPC are summarized as follows:

(1) The framework of the VRPC has been established (Figure 1), and it has been operating with the new experimental plan.

(2) Core sites were selected after full consideration of the representation of the underlying surfaces. The available remote sensing products for each site were also selected according to the observation base and land surface types. The VRPC will be constructed in several stages. Four existing stations with improved conditions have been selected for the first stage.

(3) The technical criteria for field site selection and the arrangement of remote sensing product validation need to be determined before construction of the core sites. The validation standards and guidelines of the remote sensing products need to be finished early because they are important to guide collaborative observation efforts in the future.

(4) The operation and management mechanisms of the VRPC need to be discussed by staff at the core sites. Data processing and data sharing after the observation experiment are important activities.

\section{Acknowledgments}

This research was funded by the National High-Tech Program (863) of China (grant number: 2012AA12A305; 2013AA12A301). The authors would also like to thank Youhua Ran for the preparation of Figure 3 and Yingchun Ge for the preparation of Figure 4.

\section{Author Contributions}

Xin Li created the general design of the VRPC. Tao Che participated in the design of the Heihe Station. Qing Xiao participated in the design of the Huanlai Station. Kai Zhao participated in the design of the 
Jingyuetan Station. Xiaoping Xin participated in the design of the Hulunber Station. Mingguo Ma performed the research and wrote the manuscript.

\section{Conflicts of Interest}

The authors declare no conflicts of interest.

\section{References}

1. Wang, X.M.; Gao, F.; Ma, M.G. Introduction of global land imaging satellites. Remote Sens. Technol. Appl. 2006, 21, 607-611. (In Chinese)

2. Ma, M.G.; Song, Y.; Wang, X.F.; Han, H.B.; Yu, W.P. Development status and application research of the time series remote sensing data products based on AVHRR, VEGETATION and MODIS. Remote Sens. Technol. Appl. 2012, 27, 663-670. (In Chinese)

3. Myneni, R.B.; Hoffman, S.; Knyazikhin Y.; Privette; J.L., Glassy, J.; Tian, Y.; Wang, Y.; Song, X.; Zhang, Y.; Smith, G.R.; et al. Global products of vegetation leaf area and fraction absorbed PAR from year one of MODIS data. Remote Sens. Environ. 2002, 83, 214-231.

4. Schaaf, C.B.; Gao, F.; Strahler, A.H; Lucht, W.; Li, X.W.; Tsang, T.; Strugnell, N.C.; Zhang, X.Y.; Jin, Y.F.; Muller, J.P.; et al. First operational BRDF, albedo nadir reflectance products from MODIS. Remote Sens. Environ. 2002, 83, 135-148.

5. Liang, S.L. Quantitative Remote Sensing of Land Surfaces; John Wiley \& Sons: Hoboken, NJ, USA, 2004; pp. 431-433.

6. Justice, C.; Belward, A.; Morisette, J.T.; Lewis, P.; Privette, J.L.; Baret, F. Developments in the "validation" of satellite sensor products for the study of the land surface. Int. J. Remote Sens. 2000, 21, 3383-3390.

7. Morisette, J.T.; Baret, F.; Privette, J.L.; Myneni, R.B; Nickeson, J.E.; Garrigues, S.; Shabanov, N.V.; Weiss, M.; Fernandes, R.A.; Leblanc, S.G.; et al. Validation of global moderate-resolution LAI products: A framework proposed within the CEOS land product validation subgroup. IEEE Trans. Geosci. Remote Sens. 2006, 44, 1804-1817.

8. Cohen, W.B.; Justice, C.O. Validating MODIS terrestrial ecology products: Linking in situ and satellite measurements. Remote Sens. Environ. 1999, 70, 1-4.

9. Morisette, J.T.; Privette, J.L.; Justice, C.O. A framework for the validation of MODIS land products. Remote Sens. Environ. 2002, 83, 77-96.

10. Zhang, R.H.; Tian, J.; Li, Z.L.; Su, H.B.; Chen, S.H.; Tang, X. Principles and methods for the validation of quantitative remote sensing products. Sci. China Earth Sci. 2010, 53, 741-751.

11. Wu, H.; Li, Z.L. Scale issues in remote sensing: A review on analysis, processing and modeling. Sensors 2009, 9, 1768-1793.

12. Jin, R.; Li, X.; Yan, B.P.; Luo, W.M.; Li, X.H.; Guo, J.W.; Ma, M.G.; Kang, J.; Zhang, Y. Introduction of eco-hydrological wireless sensor network in the Heihe River Basin. Adv. Earth Sci. 2012, 27, 993-1005. (In Chinese)

13. National Research Council (NRC). Observational networks. In Review of the WATERS Network Science Plan; National Academies Press: Washington, DC, USA, 2010; pp. 28-37. 
14. Liu, S.M.; Xu, Z.W.; Zhu, Z.L.; Jia, Z.Z.; Zhu, M.J. Measurements of evapotranspiration from eddy-covariance systems and large aperture scintillometers in the Hai River Basin, China. J. Hydrol. 2013, 487, 24-38.

15. Song, Y.; Wang, J.M.; Yang, K.; Ma, M.G.; Li, X.; Zhang, Z.H.; Wang, X.F. A revised surface resistance parameterisation for estimating latent heat flux from remotely sensed data. Int. J. Appl. Earth Obs. 2012, 17, 76-84.

16. Jia, Z.Z.; Liu, S.M.; Xu, Z.W.; Chen, Y.J.; Zhu, M.J. Validation of remotely sensed evapotranspiration over the Hai River Basin, China. J. Geophys. Res.: Atmos. 2012, 117, 1-21.

17. Holben, B.N.; Eck, T.F.; Slutsker, I.; Tanre, D.; Buis, J.P.; Setzer, A.; Vermote, E.; Reagan, J.A.; Kaufman, Y.J.; Nakajima, T.; et al. AERONET-A federated instrument network and data archive for aerosol characterization. Remote Sens. Environ. 1998, 66, 1-16.

18. Baldocchi, D.; Falge, E.; Gu, L.H.; Olson, R.; Hollinger, D.; Running, S.; Anthoni, P.; Bernhofer, C.; Davis, K.; Evans, R.; et al. FLUXNET: A new tool to study the temporal and spatial variability of ecosystem-scale carbon dioxide, water vapor, and energy flux densities. Bull. Am. Meteorol. Soc. 2001, 82, 2415-2434.

19. Baret, F.; Morissette, J.T.; Fernandes, R.A.; Champeaux, J.L.; Myneni, R.B.; Chen, J.; Plummer, S.; Weiss, M.; Bacour, C.; Garrigues, S.; et al. Evaluation of the representativeness of networks of sites for the global validation and intercomparison of land biophysical products: Proposition of the CEOS-BELMANIP. IEEE Trans. Geosci. Remote Sens. 2006, 44, 1794-1803.

20. Dorigo, W.A.; Wagner, W; Hohensinn, R.; Hahn, S.; Paulik, C.; Drusch, M.; Mecklenburg, S.; Oevelen, P.V.; Robock, A.; Jackson, T. The international soil moisture network: A data hosting facility for global in situ soil moisture measurements. Hydrol. Earth Syst. Sci. 2011, 15, 1675-1698.

21. Ge, Y.; Wang, J.H.; Wang, J.F.; Jin, R.; Hu, M.G. Regression kriging model-based sampling optimization design for the eco-hydrological wireless sensor network. Adv. Earth Sci. 2012, 27, 1006-1013. (In Chinese)

22. Kang, J.; Li, X.; Jin, R.; Ge, Y.; Wang J.F.; Wang J.H. Hybrid optimal design of the eco-hydrological wireless sensor network in the middle reach of the Heihe River Basin, China. Sensors 2014, 14, 19095-19114.

23. Li, X.; Li, X.W.; Li, Z.Y.; Ma, M.G.; Wang, J.; Xiao, Q.; Liu, Q.; Che, T.; Chen, E.X.; Yan, G.J.; et al. Watershed allied telemetry experimental research. J. Geophys. Res. 2009, 114, 1-19.

24. Li, X.; Cheng, G.D.; Liu, S.M.; Xiao, Q.; Ma, M.G.; Jin, R.; Che, T.; Liu, Q.H.; Wang, W.Z.; Qi, Y.; et al. Heihe watershed allied telemetry experimental research (HiWATER): Scientific objectives and experimental design. Bull. Am. Meteorol. Soc. 2013, 94, 1145-1160.

25. Jin, R.; Li, X.; Yan, B.P.; Li, X.H.; Luo, W.M.; Ma, M.G.; Guo, J.W.; Kang, J.; Zhu, Z.L.; Zhao, S.J. A nested ecohydrological wireless sensor network for capturing the surface heterogeneity in the midstream areas of the Heihe River Basin, China. IEEE Geosci. Remote Sens. Lett. 2014, 11, 2015-2019.

26. Fan, W.J.; Xu, X.R.; Liu, X.C.; Yan, B.Y.; Cui, Y.K. Accurate LAI retrieval method based on PROBA/CHRIS data. Hydrol. Earth Syst. Sci. 2010, 14, 1499-1507.

27. Fan, W.J.; Yan, B.Y.; Xu, X.R. Crop area and leaf area index simultaneous retrival based on sptial scaling transformation. Sci. China Earth Sci. 2010, 53, 1709-1716. 
28. Liu, Y.; Wang, J.D.; Zhou, H.M.; Xue, H.Z. LAI measuring data processing, analysis and spatial scaling in the middle reaches of Heihe experimental research region. Remote Sens. Technol. Appl. 2010, 25, 805-813. (In Chinese)

29. Wang, X.F.; Ma, M.G.; Li, X. Validation of MODIS GPP product at ten flux sites in northern China. Int. J. Remote Sens. 2013, 34, 587-599.

30. Yu, W.P.; Ma, M.G.; Wang, X.F.; Tan, J.L. Validation of the MODIS LST products using long wave radiation ground measurements in the north arid region of China. Remote Sens. 2014, 6, 11494-11517.

31. Che, T.; Dai, L.Y.; Wang, J.; Zhao, K.; Liu, Q. Estimation of snow depth and snow water equivalent distribution using airborne microwave radiometry in the Binggou watershed, the upper reaches of the Heihe River Basin. Int. J. Appl. Earth Obs. 2012, 17, 23-32.

32. Wang, S.G.; Li, X.; Han, X.J.; Jin, R. Estimation of surface soil moisture and roughness from multi-angular ASAR imagery in the Watershed Allied Telemetry Experimental Research (WATER). Hydrol. Earth Syst. Sci. 2011, 15, 1415-1426.

33. Cheng, G.D.; Li, X.; Zhao, W.Z.; Xu, Z.M.; Feng, Q.; Xiao, S.C.; Xiao, H.L. Integrated study of the water-ecosystem-economy in the Heihe River Basin. Natl. Sci. Rev. 2014, 1, 413-428.

34. Li, X. Characterization, controlling, and reduction of uncertainties in the modeling and observation of land-surface systems. Sci. China Earth Sci. 2014, 57, 80-87.

(C) 2015 by the authors; licensee MDPI, Basel, Switzerland. This article is an open access article distributed under the terms and conditions of the Creative Commons Attribution license (http://creativecommons.org/licenses/by/4.0/). 